us to believe that there was indeed a treatment effect.

Since reattachment of the retina and resolution of the macular hole was achieved solely with laser photocoagulation, we believe this should be the initial procedure in the management of these patients.

1 Reis W. Eine wenig bekannte typische missbildung am sehnerveneintritt: umnschiebene grubenbildung auf papilla n optici. Zeitschr Augenheilkd 1908; 19: 505-28.

$2 \mathrm{Kranenburg} \mathrm{EW}$. Crater-like holes in the optic disc and central serous retinopathy. Arch Ophthalmol 1960; 64: 912-28.

3 Brown GC, Shields JA, Goldberg RE. Congenital pits of the optic nerve head. II. Am F Ophthalmol 1980; 87: 51-65.

4 Lincoff H, Lopez R, Kreissig I, Yannuzz I, Cox M, Burton T Retinoschisis associated with optic nerve pits. Arch Ophthalmol 1988; 106: 61-7.
5 Brockhurst RJ. Optic pits and posterior retinal detachment. Trans Am Ophthalmol Soc 1975; 73: 264-88.

6 Schatz H, McDonald HR. Treatment of sensory retinal detachment associated with optic nerve pit or coloboma. Ophthalmology 1988; 95: 178-86.

7 Sugar HS. Congenital pits in the optic disc and their equivalents (congenital coloboma and colobomalike excavations) associated with submacular fluid. Am $\mathcal{F}$ Ophthalmol 1967; associated with submacular fluid. Am $\mathcal{F}$ Ophthalmol 1967;

8 Cox MS, Witherspoon CD, Morris RE, Flynn HW. Evolving
techniques in the treatment of macular detachment caused by optic nerve pits. Ophthalmology 1988; 95: 889-96.

9 Frangieh GT, Green WR, Engle HM. A histopathologic study of macula cysts and holes. Retina 1981; 1:311-36.

10 Fine SL. Vitreous surgery for macula hole in perspective. Is there an indication? Arch Ophthalmol 1991; 109: 635-6.

11 Kelly NE, Wendell RT. Vitreous surgery for idiopathic macular holes. Results of a pilot study. Arch Ophthalmol 1991; 109: 654-9.

12 Bressler NM, Finkelstein D, Sunness JS, Maguire AM, Yarian D. Retinal pigment epithelial tears through the fovea with preservation of good visual acuity. Arch Ophthalmol 1990; 108: 1694-7.

\title{
A case of presumed congenital herpes zoster ophthalmicus
}

\author{
J Singh, J M Gibson
}

Herpes zoster ophthalmicus is a disease occurring in the elderly but it only rarely occurs in children. We report an unusual case of presumed herpes zoster ophthalmicus occurring in a newborn infant. It is postulated that maternal infection with chicken pox during the second trimester of pregnancy has led to in utero transmission of the varicella virus resulting in presumed congenital herpes zoster ophthalmicus. This is the first report of such a case to our knowledge.

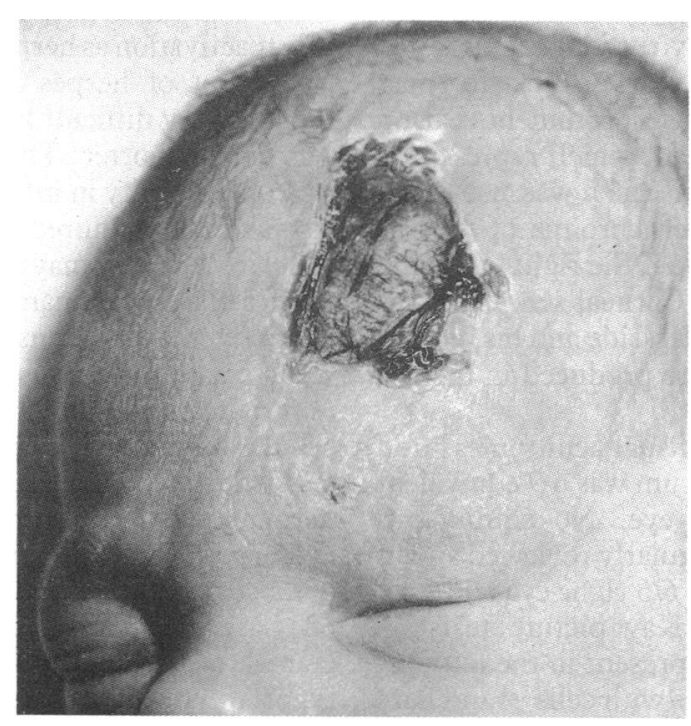

Figure 1 Newborn infant. A full thickness skin defect is seen in the ophthalmic division of the trigeminal nerve.

\section{Case report}

A mother who contracted chicken pox at the beginning of the second trimester of pregnancy, gave birth to a 7 week preterm infant boy, weighing $2 \cdot 1 \mathrm{~kg}$. Maternal chicken pox infection was confirmed by the presence of a typical generalised rash in association with significantly raised IgM titres suggesting a recent infection.

At birth it was found that the boy had a large full thickness skin defect exposing the skull bones in the distribution of the ophthalmic

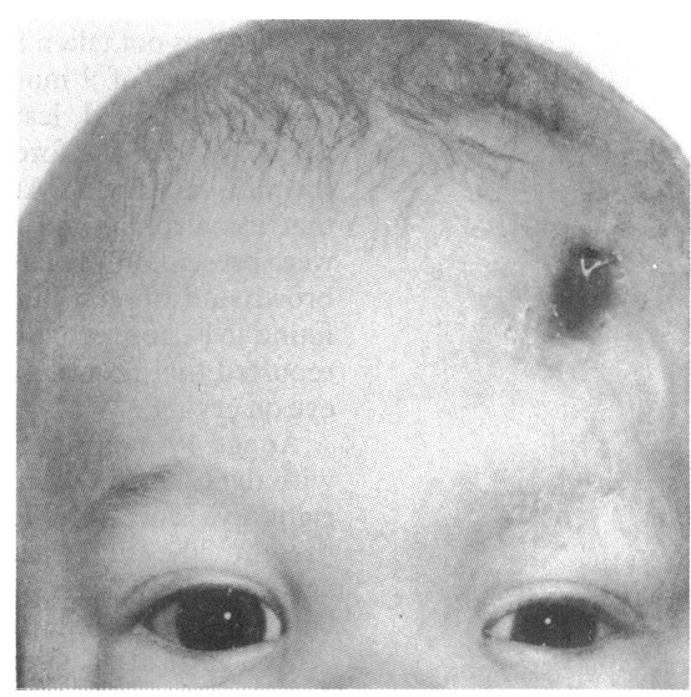

Figure 2 Aged 5 months. Healing skin defect. The extent of the original affected area of skin can be seen from the surrounding scarring. It respects the mid-line. 


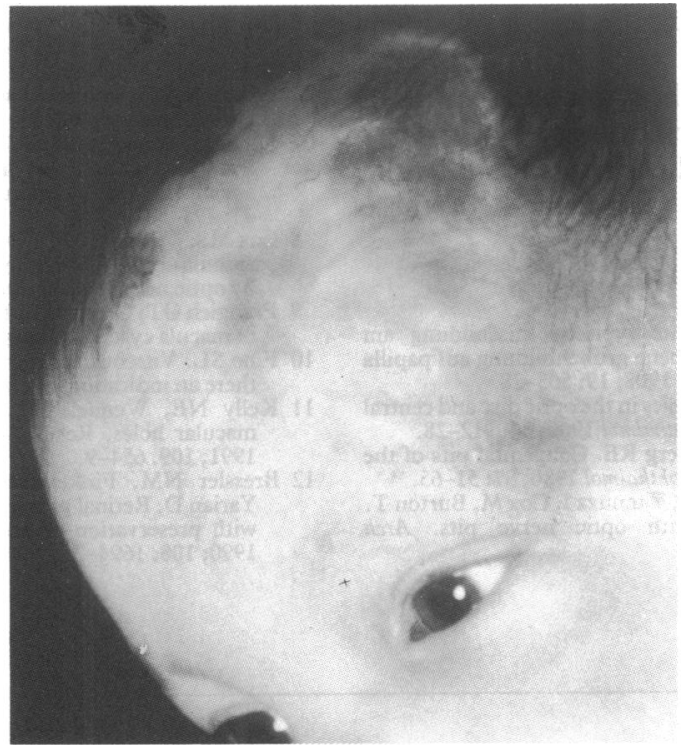

Figure 3 Aged 9 months. Skin defect fully healed. Large scar is present.

division of the trigeminal nerve (Fig 1). Associated with this was a cicatrising skin lesion affecting the upper eyelid, and a small degree of ptosis of the upper eyelid. The left pupil was dilated and unreactive to light, but it had a normal afferent pupil reflex. Fundus examination, after dilating the pupil showed normal optic discs, retinal vessels, and retinas when examined with the binocular indirect ophthalmoscope, and there was no significant refractive error present. The scalp defect slowly started to heal and by 5 months of age was already much smaller (Fig 2).

The child suffered recurrent attacks of conjunctivitis in the left eye and Staphylococcus aureus was cultured during one of these episodes; the conjunctivitis settled quickly with gentamicin eye drops. At age 6 months the child developed a vesicular rash around the left side of the trunk in a dermatomal distribution with a few generalised vesicles on the arms and face. These lesions resolved spontaneously. Serological tests were performed but did not show any rise in antibody production. Unfortunately fluid from the vesicles was not taken for virus identification.

By the age of 9 months the scalp defect had completely healed, leaving a prominent scar on the left side of the forehead, which represented the mid-line (Fig 3). At this age it was also noted that iris atrophy and heterochromia of the iris were present on the left side, the right iris being brown and the left blue. Corneal sensation was found to be absent on the left side and his mother reported that no tears were produced in the left eye on crying.

At age 19 months the visual acuity measured with the Catford Oliver drum was $6 / 9$ equivalent right eye and 6/12 left eye. No squint was present. The child was regularly reviewed and at age 26 months vision was $6 / 6$ right eye and only 6/36 left eye, with the Kay picture tests. A central corneal ulcer was present in the left eye, with a mild anterior uveitis with cells + and flare + . The eye was treated with acyclovir ointment five times daily for 5 days and after 1 week the ulcer had healed leaving a small axial corneal scar, and a quiet eye.

After the ulcer had healed, visual acuity had deteriorated to $3 / 60$ in the left eye with Kay picture tests and this was assessed as being partly due to the corneal scarring and perhaps partly due to stimulus deprivation amblyopia. Once the eye had settled he received occlusive treatment to the right eye, and by age 28 months vision was $6 / 60$ in the left eye and at age 30 months 6/24 with the Kay picture tests.

The vision has continued to improve, despite subsequent further episodes of keratitis that have been promptly treated with acyclovir ointment and have responded well.

At his most recent review, aged 3 years 9 months, visual acuity with the Sheridan-Gardner test, was recorded as 6/6 right and 6/12 left. There is no obvious squint present on cover test examination and his ocular movements are full. There is a small thickened and erythematous area on his upper eyelid, but otherwise most of the prominent scar on the forehead is covered by normal hair. Corneal sensation is absent, and there is fine staining of the cornea with fluorescein in the interpalpebral fissure and the eye is clinically dry. The anterior chamber is quiet, the intraocular pressure is normal (by non-contact tonometry), and fundus examination shows no abnormalities. He is being treated with hypromellose eye drops and Simple ointment at night to the left eye.

\section{Comment}

Varicella and herpes zoster viruses are thought to be homogeneous and although antigenically different both viruses cause the same cytopathic effect. ${ }^{1}$ The primary response to varicella is chicken pox and reactivation of dormant virus in a sensory root ganglion leads to herpes zoster (shingles). The time from primary infection to reactivation in the vast majority of cases is many years so that shingles is usually a disease of the elderly. ${ }^{2}$

There are a number of reports of herpes zoster occurring in children. ${ }^{3-10} \mathrm{~A}$ large number of these particular cases have shown that the primary infection was maternal chicken pox with probable reactivation as herpes zoster in the offspring. The onset of herpes zoster in these children shows a very difficult time scale to adults, being very much shorter. This may be explained by a lack of immunity in infants allowing reactivation of varicella acquired antenatally." Impaired cellular immunity may also explain other features of varicella zoster, namely, inability to produce antibody to this virus and the occurrence of recurrent herpes zoster infections. ${ }^{12}$ The child in this case report may have had impaired cellular immunity explaining negative serological tests despite clinical evidence of a second dermatomal zosteriform eruption.

Herpes zoster affecting the trigeminal nerve has also been described in infants ${ }^{1012-14}$ including one case in which all three divisions of the fifth cranial nerve were involved." All these cases report a typical dermatomal skin rash; however, there is no case where this skin lesion is associated with an ocular abnormality in infants. 
Table 1 A comparison of ocular features of congenital varicella syndrome and herpes zoster ophthalmicus

\begin{tabular}{|c|c|}
\hline $\begin{array}{l}\text { Ocular features of congenital } \\
\text { varicella syndrome } e^{1017} 18\end{array}$ & $\begin{array}{l}\text { Ocular features of herpes zoster } \\
\text { ophthalmicus } 21\end{array}$ \\
\hline $\begin{array}{c}\text { Cicatrising dermatomal skin } \\
\text { lesions }\end{array}$ & $\begin{array}{l}\text { Cicatrising dermatomal skin } \\
\text { lesions and ptosis }\end{array}$ \\
\hline Chorioretinitis & Mucopurulent conjunctivitis \\
\hline Optic atrophy & Episcleritis and scleritis \\
\hline Anisocoria & Corneal anaesthesia \\
\hline Nystagmus & Recurrent keratitis \\
\hline Microphthalmia & Uveitis \\
\hline Cataract & Iris atrophy \\
\hline Corneal opacity & Glaucoma \\
\hline Heterochromia & $\begin{array}{l}\text { Ciliary ganglionitis causing } \\
\text { abnormal pupil response } \\
\text { Optic neuritis }\end{array}$ \\
\hline
\end{tabular}

Ophthalmologists will be interested in another distinct teratogenic effect of varicella zoster. The virus once acquired in pregnancy is able to cross the placenta causing systemic and ocular problems in the offspring. This association was first noted in $1947^{15}$ and has subsequently been recognised as the congenital varicella syndrome or the fetal varicella syndrome. ${ }^{1016-18}$ The ocular associations of congenital varicella and shingles are depicted in Table 1. The case we have described does not show many of the ocular findings in congenital varicella syndrome but does illustrate many of the clinical features of adult herpes zoster ophthalmicus: a dermatomal skin lesion in the distribution of the ophthalmic division of the trigeminal nerve, absent corneal sensation, recurrent keratitis and uveitis, iris atrophy, and abnormal direct pupil response. Other conditions that may cause skin defects are direct pressure on the fetus in utero or cutaneous polyarteritis, a rare vasculitis in children. ${ }^{19}$ However, the dermatomal distribution and ocular features make these latter two conditions unlikely.

In conclusion, we suspect that the mother's varicella infection in pregnancy and the child's congenital conditions are causally related. The varicella zoster virus probably crossed the placenta to lie dormant in the child's trigeminal ganglion. At some time before birth the virus was reactivated ${ }^{20}$ and led to this unique case of 'presumed herpes zoster ophthalmicus' in utero which was present at birth. The clinical findings are so unusual and similar to adult herpes zoster ophthalmicus, that this seems the most likely explanation.

1 Weller TH. Varicella and herpes zoster. Changing concepts of the natural history, control and importance of a not-so benign virus. $N$ Engl f Med 1983; 309: 1362-8; 1434-40.

2 Liesegang TJ, Rochester MN, The varicella zoster virus. Systemic and ocular features. $f$ Am Acad Dermatol 1984; 11 : 165-91.

3 Bonar BE, Pearsall CJ. Herpes zoster in the newborn. Am $\mathcal{F}$ Dis Child 1932; 44: 398-402.

4 Brunell PA, Miller LH, Lovejoy F. Zoster in children. Am f Dis Child 1968; 115: 432.

5 Lyday JH. Report of severe herpes zoster in a 131/2 year old boy whose chicken pox infection may have been acquired in whose chicken pox infection may
utero. Pediatrics 1972; 50: 930-1.

6 McKendrick DGW, Raychoudhury SC. Herpes zoster in childhood. Scand f Infect Dis 1972; 4: 23.

7 Lewkonia IK, Jackson AA. Infantile herpes zoster after intrauterine exposure to varicella. $B M \mathcal{F}$ 1973; $3: 149$.

8 Brunell PA, Kotchmar GS. Zoster in infancy: failure to maintain virus latency following intrauterine infection. f Pediatr 1981; 98: 71-3.

9 Dwonsky $M$, Whitley $R$, Alford C. Herpes zoster in early

infancy. $A m \mathcal{F}$ Dis Child $1980 ; 134: 618$.
10 Gershon AA. Chicken pox, measles and mumps. In: Remington JS, Klein JO, eds. Infectious diseases of the fetus and newborn infant. 3rd ed. 1990: 395-445.

11 David TJ, Williams ML. Herpes zoster in infancy. Scand $f$ Infect Dis 1979; 11: 185-6.

Infect Dis 1979; 11: 185-6.
12 McMurray JB. Herpes zoster ophthalmicus in an infant of 15 months. Am $\mathcal{F}$ Ophthalmol 1928; 11: 51 .

13 Kock FLP. Herpes zoster ophthalmicus - report of a case. Arch Ophthalmol 1939; 21: 118-20.

14 Adkisson MA. Herpes zoster in a newborn premature infant. $\mathcal{F}$ Pediatr 1965; 66: 956-8.

15 La Foret, Lynch LL. Multiple congenital defects following maternal varicella. $N$ Engl f Med 1947; 236: 534-7.

16 Strabstein JC, Morris N, Larke RBP. Is there a congenital varicella syndrome? F Pediatr 1974; 84: 239-43.

17 Charles NC, Bennett TW, Margolis S. Ocular pathology of the congenital varicella syndrome. Arch Ophthalmol 1977; 95: 2034-7.

18 Alkalay AL, Pomerance JJ. Fetal varicella syndrome. 7 Pediatr 1987; 111: 320-3.

19 Forfar and Ameil's Textbook of Paediatrics. 4th ed. 1992: 1683-6.

20 Higa K, Dan K, Manabe H. Varicella zoster virus infections during pregnancy: hypothesis concerning the mechanism of congenital malformations. Obstet Gynecol 1987; 69: 214-22.

21 Karbassi M, Raizman MB, Schuman JS. Herpes zoster ophthalmicus. Surv Ophthalmol 1992; 36: 395-410.

\section{Orbital multiple myeloma mimicking acquired angio-oedema}

Medical University of
South Carolina
Department of
Dermatology
R L Snider
B H Thiers
Department of
Ophthalmology
G R Howard
Correspondence to:
Rebecca L Snider, MD,
Department of Dermatology,
Medical University of South
Carolina, 171 Ashley Ave, CSB
623, Charleston, SC 29425-
2215, USA.
Accepted for publication
8 March 1993

\author{
Rebecca L Snider, Bruce H Thiers, Gene R Howard
}

Multiple myeloma is characterised by malignant plasmacytes in the bone marrow and excessive production of specific immunoglobulins or immunoglobulin components. Ocular involvement may result from myelomatous infiltration or may occur secondarily to haematological abnormalities. Virtually any ocular structure can be involved, including the conjunctiva, cornea, sclera, lens, retina, uveal tract, optic nerve, lacrimal glands, and orbit. ${ }^{1}$ Involvement of periorbital skin is unusual. To our knowledge this is the first reported case of metastatic multiple myeloma presenting as periorbital swelling with angio-oedema-like features.

\section{Case report}

A 58-year-old white woman presented to her 